\title{
FAMILY ENTERPRISES IN THE RURAL AREAS OF THE SOUTHWEST REGION IN THE REPUBLIC OF NORTH MACEDONIA
}

\author{
Tošo Kostadinov \\ ${ }^{1}$ Institute of Animal Science, Ss. Cyril and Methodius University in Skopje, \\ Blvd. Ilinden 92a, Skopje, Republic of North Macedoni \\ tosokostadinov@gmail.com
}

\begin{abstract}
A b s t r a c t: The aim of this paper is to investigate some aspects of family enterprises and incorporate new findings in the body of knowledge about family businesses in rural areas of the Southwest planning region of the Republic of North Macedonia. With that in mind, 25 individuals from rural parts from the Southwest planning region in the Republic of North Macedonia were interviewed, of whom $41.62 \%$ were owners of family businesses and 58.47 of non-family businesses. They were offered five sets of statements that are of importance for comparison between family and non-family businesses and determining the specifics of family businesses in rural areas of the Southwest planning region. The responses were measured at a five-level scale from irrelevant to those of priority. From the results of the conducted research it can be concluded that family businesses significantly shape the economic environment in the rural areas of the Southwest planning region. General support for entrepreneurship and SMEs in rural areas of the Southwest planning region by the local governments can significantly stimulate the establishment of new family enterprises and the growth of existing ones.
\end{abstract}

Key words: Southwest planning region; Republic of North Macedonia; family enterprises; rural areas; entrepreneurship

\section{СЕМЕЈНИТЕ ПРЕТПРИЈАТИЈА ВО РУРАЛНИТЕ ПОДРАЧЈА НА ЈУГОЗАПАДНИОТ РЕГИОН НА РЕПУБЛИКА СЕВЕРНА МАКЕДОНИЈА}

\begin{abstract}
А п с т р а к т: Целта на овој труд е да се испитаат некои аспекти на семејните претпријатија и да се вклучат нови наоди во телото на знаење за семејните бизниси во руралните области на Југозападниот плански регион на Република Северна Македонија. Имајќи го тоа на ум, беа интервјуирани 25 лица од руралните делови од Југозападниот плански регион на Република Северна Македонија, од кои 41,62\% беа сопственици на семејни бизниси и $58,47 \%$ на не-семејни бизниси. На нив им беа понудени пет групи изјави што се од значење за споредба помеѓу семејни и не-семејни бизниси и за одредување на спецификите на семејните бизниси во руралните области на Југозападниот плански регион. Одговорите беа измерени на скала од пет нивоа, од ирелевантни до оние со приоритет. Од резултатите од спроведените истражувања може да се заклучи дека семејните бизниси значително ја обликуваат економската средина во руралните области на Југозападниот плански регион. Општата поддршка на претприемаштвото и МСП во руралните области на Југозападниот плански регион од страна на локалните власти може значително да го стимулира формирањето на нови семејни претпријатија и растот на постојните.
\end{abstract}

Клучни зборови: Југозападен плански регион; Република Северна Македонија; семејни претпријатија; рурални области; претприемаштво

\section{INTRODUCTION}

Numerous and diverse definitions of family businesses are found in the literature, hence there is no consensus in its definition. The range of multiple definitions brings with it many ambiguities. Family businesses are multidimensional and no one definition can fully capture their internal diversity. Research on family businesses suggests that there are more than 90 definitions of what a family business is [1]. Although anyone can understand and define this type of business, it must be noted that 
defining it is a particularly difficult task, especially for an area that is under development. This shows that even in the same country several different definitions can be used. Regarding the number of definitions for family businesses, a group of authors concluded that due to the unique institutional-legal contexts in countries around the world, it makes no sense to come up with a definition that could be universally applicable [2].

Family business can be defined in terms of ownership, intergenerational transfer of business, in terms of interdependence of subsystems, in terms of culture, in terms of strategic management and the like [5]. The broader general definition of a family business is that "a family business is a firm where a family has sufficient capital to be able to control the family business management strategy" [3].

This definition transfers time and space and is one of the most used poses today.

Not all family businesses are the same, so it would be wrong to understand the name family businesses as a kind of business model. All family businesses develop differently, depending on the ownership style of each family.

In the practice of operating these businesses there are several types of family businesses, as follows [5]:

- Unique practitioner. - This is a type of business that resembles a man-band, means that the owner is the one who makes all the key decisions in the company. Most of the family businesses are engaged in this type of business, and the founder is presented as the owner and entrepreneur. In this type of business there is a situation where the owner shows a strong attachment to the company and hardly shares control with another member.

- Related partners. - This is not a mandatory formal partnership in the legal sense of the word. The merger of different entrepreneurs can take various forms, such as a limited liability company, corporation or other enterprise. This type of business is founded by two or more entrepreneurs, usually brothers, sisters, cousins, etc., who take ownership in various aspects of the business.

- Family-controlled businesses, as opposed to family-influenced businesses. This is also a fundamental area in which family businesses can be significantly different. In family-controlled businesses, the family member is not only the owner of the business, but also has an active role in managing and running the business. In contrast, in family-influenced businesses, the family does not play an active role in running the business, but running the business can be outsourced to key employees who may be better suited for certain roles than family members. Family members can have varying degrees of control over this business model, from board positions to holding a majority stake in the company.

Another characteristic division of family businesses is made according to the fact that every family business grows and develops over time, so the opportunities of the family increase. Hence, family businesses can be divided into:

- Active family businesses characterized by personal management and supervision of operations by family members. The ownership of the company is in the hands of the family who are part of the business process and who are employed in the company. Such companies often employ a number of non-family employees.

- Family businesses with an absent owner are those that are owned but also controlled by family members who are not employed in the company and do not manage their business. The company is managed by non-family members in the name and on behalf of the family.

- Latent (hidden) businesses are those businesses where only one member of the family, usually the owner or legitimate heir, is involved in the business process or running the business, as a rule as president. Other family members will eventually be involved in the family business in the future.

\section{MATERIAL AND METHODS}

The research is based on literature, documents and particularly on analysis of a suitable sample of interviewed entrepreneurs (25 SMEs) from rural areas of the Southwest planning region in the Republic of North Macedonia which were conducted in 2018 - of which $41.53 \%$ were family businesses and $58.47 \%$ non-family, and the aim is to obtain a certain amount of knowledge regarding the conditions of family businesses in that particular region. During the creation of this work several methods were applied which are usually used for economics analysis, mainly the comparative method, the method of generalization and specialization, the methods of induction and deduction and the statistical method. 
In this survey research several sets of statements were presented to the interviewes that are of importance for comparison between family and non-family businesses and for the assessment of the conditions of family enterprises in the rural areas of the Southwest planning region in the Republic of North Macedonia, assessed according a five level scale from 1 (unimportant) to 5 (of priority).

\section{RESULTS AND DISCUSSION}

Collected and processed data are displayed in Tables 1, 2, 3, 4 and 5.

In the group of questions related to the promotion of the company to be more competitive in the market, compared to the business (family / non-family), there is a significant difference in the statement "association of companies from my sector for joint market entry", for which family businesses have a more positive attitude.

On the questions related to the plans for the future business, compared to the business (family / non-family), the highest grade was obtained for the statement "adding a new product or service", by the representatives of the non-family businesses. Family businesses emphasize the need to seek additional financial capital.

By non-family businesses, investing in employee training (elsewhere / not in the firm) is the lowest rated.

Compared to rural areas in Serbia, where family businesses are also showing enviable results, although they are often seen at the beginning as a less serious way of earning a living, until such businesses do not start to grow into larger companies [4], our research on family businesses confirms this in the Southwest planning region of our country.

Similar results have been obtained in research in rural areas in Croatia where families starting their own businesses are innovative, generate many new ideas and drive the market to introduce many changes [6].

\section{Table 1}

Consent of the assertion from the aspect of promotion of operating for a more competitive market position compared to family / non-family business

\begin{tabular}{lll}
\hline & \multicolumn{2}{c}{ Average value } \\
\hline Improving the quality of products / services & Family & Non-family \\
Improving product promotion & 4.25 & 4.16 \\
Obtaining quality certificates & 4.14 & 4.26 \\
Professional consulting assistance & 3.84 & 4.21 \\
Training and education in the field of entrepreneurship & 3.51 & 3.45 \\
Training and education in the field of informatics & 3.70 & 3.90 \\
Training and education in the field of management & 3.70 & 4.08 \\
Training and education in the field of finance & 3.72 & 3.99 \\
Training and education in the field of sales & 3.41 & 3.82 \\
Training and education in the field of marketing & 3.83 & 3.96 \\
Training and education in the field of foreign languages & 3.88 & 3.90 \\
Association of companies from my sector for the purpose of joint market appearance & 3.60 & 3.38 \\
Help with development programs through grants & 4.45 & 3.13 \\
Assistance from development programs with favorable loans & 4.46 & 3.75 \\
Assistance from development programs through guarantee funds & & 4.23 \\
\hline \hline
\end{tabular}


Table 2

Consistency of claims in terms of future business plans, compared to the type of business (family / non-family)

\begin{tabular}{lcc}
\hline \hline & \multicolumn{2}{c}{ Average value } \\
& Family & Non-family \\
\hline Adding a new product or service & 4.10 & 4.14 \\
Selling in a new market & 3.69 & 3.14 \\
Exploring new markets & 3.69 & 3.12 \\
Finding new distribution channels & 3.99 & 3.38 \\
Expand advertising and promotion & 4.12 & 3.77 \\
Investing in new devices and machines & 4.07 & 3.39 \\
Replacement of current devices and machines & 4.27 & 3.46 \\
Expansion of current plants & 4.19 & 3.33 \\
Redesign / new layout of current plants & 3.75 & 3.16 \\
Request for additional financial capital & 4.14 & 3.46 \\
Computerization of current operations & 3.63 & 2.99 \\
Upgrading computer systems & 3.56 & 3.06 \\
Redesign of work activities & 3.70 & 2.98 \\
Expanding the scope of work activities & 4.00 & 3.57 \\
Seek professional or technical advice & 3.82 & 3.10 \\
Additional engagement of employed specialists & 3.80 & 3.05 \\
Investing in employee training (elsewhere / not in the company) & 2.97 & 2.40 \\
\hline \hline
\end{tabular}

Table 3

Compatibility of the entrepreneurship claim by type of family / non-family business

\begin{tabular}{lcc}
\hline \hline & \multicolumn{2}{c}{ Average value } \\
& Family & Non-family \\
\hline My business is the most important activity in my life & 4.18 & 4.05 \\
I would do whatever it takes to make my business a success & 4.28 & 4.18 \\
I plan to sell it at the end of the business & 2.29 & 2.11 \\
I would like to contribute significantly to the community by developing a successful business & 4.35 & 4.20 \\
I would rather have my own business than earn a higher salary by working for someone else & 4.26 & 3.91 \\
Running your own business is more important than having more time for your family & 3.60 & 3.97 \\
I would rather have my own business than have another promising career & 3.98 & 4.16 \\
It is important for the entrepreneur to understand and accept the risk to start and run a successful business & 4.23 \\
I am ready to enter into conflict with my family to run my business & 3.61 \\
I would mortgage my house to provide capital for my business & 3.64 & 3.29 \\
I would be willing to have less security for my family in order to run my business & 3.58 & 3.49 \\
I run my business to continue the family tradition & 3.55 & 3.21 \\
I run my own business to contribute to the well-being of my relatives & 3.46 & 3.56 \\
I run my business to live in a place that my family wants & 3.37 & 3.55 \\
I run my business to improve the status and prestige of my family & 4.04 & 4.04 \\
I run my business to have more flexibility in my personal and family life & 4.23 \\
\hline \hline
\end{tabular}


. T a b l e 4

Consistency of claims in the community, compared to the type of business (family / non-family)

\begin{tabular}{lcc}
\hline \hline & \multicolumn{2}{c}{ Average value } \\
& Family & Non-family \\
\hline Many people in my community would love to start and grow a business & 2,69 & 2,79 \\
Many people in my community really support entrepreneurs when they fail and try a new business again. & 2,69 & 2,56 \\
Many people in my community support someone who is creating a new or expanding existing business & 2,69 \\
Many people in my community would encourage a younger person to pursue a career in creating and & 3,17 & 2,63 \\
growing a business. & 3,10 & 2,89 \\
Many people in my community would love to start and grow a business &
\end{tabular}

Table 5

Consistency of claims from the aspect of supporting entrepreneurship, compared to the type of business (family/non-family)

\begin{tabular}{|c|c|c|}
\hline & \multicolumn{2}{|c|}{ Average value } \\
\hline & Family & Non-family \\
\hline My community respects and celebrates the people who create and grow local businesses & 2,61 & 2,99 \\
\hline $\begin{array}{l}\text { My community has developed programs to encourage and support entrepreneurs involved in growth } \\
\text { and development }\end{array}$ & 2,44 & 2,88 \\
\hline My community is considering micro-lending programs & 2,44 & 2,88 \\
\hline My community offers business or entrepreneurship training & 2,69 & 3,21 \\
\hline $\begin{array}{l}\text { My community creates conditions for networking and monitoring opportunities for entrepreneurs and } \\
\text { local businesses }\end{array}$ & 2,39 & 2,99 \\
\hline My community needs venture capital and / or angel investors & 3,28 & 3,56 \\
\hline
\end{tabular}

In the group of questions related to the attitudes towards entrepreneurship, compared to business (family / non-family), most of the respondents with family businesses, state that they would like to significantly contribute to the community through the development of a successful business.

The lowest rating was given by the representatives of non-family business for the attitude that they plan to sell it at the end of the business.

The biggest difference in the answers of the respondents is noticed in the attitude 'I run my business in order to have more flexibility in my personal and family life', and the same was higher evaluated by the representatives of non-family business.

Family businesses invest more in enterprise development than non-family businesses. [7]. The results we conducted in the researched rural areas of the researched region confirmed this conclusion of the foreign authors
In the group of questions related to the community attitudes towards entrepreneurs, compared to business (family / non-family) there are no significant differences in the ratings in relation to this group of questions. Representatives of family businesses gave slightly higher grades. The only exception is the view that many people in their community would like to start and grow a business.

The results of another study [6] also claim that in the rest of the world, as well as in Croatia, more and more attention is paid to family entrepreneurship, something that was confirmed by our research.

In the group of questions related to entrepreneurship support, compared to business (family / non-family), the representatives of non-family businesses gave slightly higher marks for these views.

The highest rated is the attitude of the community for the need for venture capital and / or angelsinvestors, given by the respondents in non-family businesses. 
The most skeptical are the representatives of the family business regarding the opinion that their community creates conditions for networking and monitoring the opportunities for entrepreneurs and people from the local business.

In general, discussing this topic, we can say that in the rural areas of the Southwest region in the Republic of North Macedonia most of the family businesses are small and medium enterprises, although any precise information on this issue is not available. Concentration in some industries, social factors, including average wages, labor, etc., contribute to the expansion of family businesses in certain sectors. For example, they are predominantly present in the retail trade, then in the wood processing industry, in the wine sector, a large number of families are engaged in agriculture, and some of them have registered their own companies that are in some way registered as family businesses. Many clothing companies have also started and run as family businesses. It is expected that in the near future family businesses, as a form of business organization, will expand to other spheres of social life in the rural areas of the region, such as: tourism, consulting services, fashion and design, as well as services in the IT sector.

For the most part, start-ups and family businesses are innovative, using new materials and process technologies, enabling a multidisciplinary approach and paving the way for success and development. Most often, these are businesses where family communication, family understanding and respect are high, so conflict situations are minimized. At the same time, the advantage of this business is that the descendants inherit both knowledge and experience.

In addition to the advantages, family businesses in the rural areas of the region also face numerous weaknesses and disadvantages that make them unsustainable in the long run. Some of the most important are the following: poor knowledge of management, i.e. lack of professional management, nepotism, minimal marketing, lack of business plan, attending seminars and trainings, problems with access to finance for further development, inadequate cost control, and in some of them and inappropriate interpersonal relationships that exist between the staff in the company, lack of discipline.

Hence, as future perspective solutions in facing such problems and challenges, which generally apply to family businesses in the rural areas of the Southwest region of the Republic of North Macedonia are the following: raising public awareness to improve their competencies for doing business, which will greatly contribute to making positive decisions for starting a family business; to facilitate access to finance; to ensure timely preparation of business transfers, i.e. inheritance; to manage the family properly; to retain a skilled workforce; and of course attend training on managing specific family businesses.

\section{CONCLUSION}

From the results of the conducted research it can be concluded that family businesses significantly shape the economic environment in the rural areas of the Southwest planning region. General support for entrepreneurship and SMEs in rural areas of the Southwest planning region by the local governments can significantly stimulate the establishment of new family enterprises and the growth of existing ones.

As future perspective solutions in facing such challenges, which generally apply to family businesses in the rural areas of the Southwest region of the Republic of North Macedonia are the following: raising public awareness in order to improve their competencies for doing business, which to a large extent will contribute to making positive decisions for starting a family business; to facilitate access to finance; to ensure timely preparation of business transfers, i.e. inheritance; to manage the family properly; to retain a skilled workforce; and of course attend training on managing specific family businesses.

In general, entrepreneurship and family businesses in the rural areas of the region have a good perspective, but still need to take an active part in their further growth and development. In this context, among other things, it is necessary to move towards the adjustment of the legislation and the opening of funds with easier access to financial resources in order to facilitate the possibility of financing the start-up businesses of potential investors.

\section{REFERENCES}

Parada Balderrama, M. J. (2016): Understanding different dimensions of the family business from contingency perspective, Tesis Doctorals, Universitat Ramon Llull, Departament de Direcció General i Estratègia i de Direcció de Persones i Organització, http://hdl.handle.net/10803/352716.

Carney, M. (2005): Corporate governance and competitive advantage in family-controlled firms, Entrepreneurship: Theory and Practice, vol. 29, no. 3, 249-265 https://doi.org/10.1111/j.1540-6520.2005.00081.x 
Colli A., Rose M. (2008): Business History: Forms of Bussiness Organization - chapter 9 Family Businnes, Oxford University Press,

Mašović, I., Catović, A., Elfić, E. (2017): Specifičnosti porodičnog biznisa u Srbiji, Ekonomski izazovi, godina VI, broj 12, str. 82-93.

Fletcher, D. E. (2002): Understanding the small family business, London, Routldge, UK.
Renko, N., Kuvačić, D., Renko S. (2007): Analiza empiriskog istrazivanja o obiteljskom poduzetništvu u Republici Hrvaskoj, izvorni znanstveni rad, Ekonomski pregled, 58 (1-2) str. 72-90.

Udovčić, A. (2011): Malo i srednje poduzetništvo u Hrvatskoj s osvrtom na obiteljsko poduzetništvo, izvorni znanstveni članak, Zbornik radova Veleučilišta u Šibeniku, Veleučilište u Šibeniku, str. 405-416. 
